\title{
Does educational aspect solve immigration problems in France?
}

\section{¿El aspecto educativo resuelve los problemas de inmigración en Francia?}

\author{
Alexander Anatolevich Khokhlov \\ Senior Lecturer, Department of history of Tatarstan, archeology and Ethnology, Institute of \\ International Relations, Kazan Federal University \\ Orcid: 0000-0003-2920-0287,
}

\begin{abstract}
Almaz Vasilovich Zakirov
Senior Lecturer, Department of international relations, world politics and diplomacy, Institute of International Relations, Kazan Federal University

Orcid: 0000-0003-4562-897X

Ildar Kimovich Kalimonov

Senior Lecturer, Department of regional studies and Eurasian studies, Institute of International Relations, Kazan Federal University

Orcid:0000-0001-6322-2426
\end{abstract}

Received 09-08-20 Revised 10-10-20

Accepted 20-12-21 On line 03-17-21

\section{* Correspondence}

Email: a_radiance@mail.ru 


\section{Summary}

International immigration with different reasons such as education and citizenship is by no means a new phenomenon in the modern global world. Nevertheless, intense immigration was sparked and had serious implications, especially for European countries like France after the year 2010, which marked the start of the revolution in Tunisia and the birth of such a phenomenon as the Arab spring. After the end of the colonial era and the loss of colonial possessions by France, the French state encountered the problem of the influx of an infinite number of Arab and African immigrants who had considerable ethnic, religious and cultural-historical characteristics. Exacerbating the problem was that the distinctions seemed essential even when compared with immigrants from other countries, for example, Eastern and Southern Europe. The latter had a relatively similar culture and mentality to the French, and what is the main - a common Christian value matrix. As such, they did not become a problem for the governmental policy of integrating into the cultural space of the host country. European immigrants easily sipped republican values, legal norms, traditions and customs, while making a break with their tradition of the past. However, the growth of immigrant population belonging to a different culture and religious heritage led to the fact that the strategy of the French state in this direction began to become ineffective. It is obvious that the old mechanisms of adaptation, such as obtaining French citizenship and education, do not solve emerging problems, but only generate new ones. As a result, a mutual rejection of the indigenous population and the newcomers intensified, stimulating a buildup of tension in society. As a result, this gradually turned into a matter of preserving national identity for the former, while into a matter of ensuring the survival of themselves and their children for the latter.

Keywords: Citizenship, education policy, international relations, international life, migration of population, immigrant problem.

\section{Resumen}

La inmigración internacional no es de ninguna manera un fenómeno nuevo en el mundo global moderno. Sin embargo, se desató una intensa inmigración que tuvo serias implicaciones, especialmente para países europeos como Francia después del año 2010, que marcó el inicio de la revolución en Túnez y el nacimiento de un fenómeno como la primavera árabe. Tras el fin de la era colonial y la pérdida de las posesiones coloniales por parte de Francia, el Estado francés se encontró con el problema de la afluencia de un número infinito de inmigrantes árabes y africanos que tenían considerables características étnicas, religiosas y cultural-históricas. El problema se agravaba porque las distinciones parecían esenciales incluso cuando se las comparaba con inmigrantes de otros países, por ejemplo, Europa del Este y del Sur. Este último tenía una cultura y una mentalidad relativamente similar a la de los franceses, y lo que es más importante, una matriz de valores cristiana común. Como tales, no se convirtieron en un problema para la política gubernamental de integración en el espacio cultural del país anfitrión. Los inmigrantes europeos saborearon fácilmente los valores republicanos, las normas legales, las tradiciones y las costumbres, mientras rompían con su tradición del pasado. Sin embargo, el crecimiento de la población inmigrante perteneciente a una cultura y herencia religiosa diferente llevó a que la estrategia del Estado francés en esta dirección comenzara a ser ineficaz. Es obvio que los viejos mecanismos de adaptación, como la obtención de la ciudadanía y la educación francesas, no resuelven problemas emergentes, solo generan otros nuevos. Como resultado, se intensificó el rechazo mutuo de la población indígena y los recién llegados, lo que estimuló una acumulación de tensión en la sociedad. Como resultado, esto se convirtió gradualmente en una cuestión de preservar la identidad nacional para los primeros, mientras que en una cuestión de asegurar la supervivencia de ellos mismos y de sus hijos para los segundos.

Palabras clave: ciudadanía, política educativa, relaciones internacionales, vida internacional, migración de la población, problema de los inmigrantes. 


\section{Introduction}

In the modern world, population shift is a fact of life. Moving from country to country in America or Europe is not associated with a sense of danger. Why, then, there is an appearing sensitivity towards migratory stream from Asian and African countries to Western Europe? Thinking back on the history, then Western European civilization had sprung up from the Migration period. Mass migrations in Europe also took place later. In the 20th century there was wide-scale migration, and after the Second World War there was a mass migration of low-cost labor from countries emerged from colonial bondage this century. There was much gain from it at that time and no one objected in principle. In France, the Maghreb mercenaries who were recruited to serve in the French army during the First World War were joined by migrants during the economic boom of the 1960s, when there was a shortage of manual workers in factories. In 1962 the Algerian population in France was 350,000 (Demitseva E. Being an Arab in France. M.: New Literary Review, 2008).

At the beginning of the 20th century, France had a tough time concerning its population. There were less births than deaths in France, the French population gradually declined. The government's solution proposal was to open up the country to foreign immigrants to make up for the shortage in the 1920s. After the end of World War Two, the rise in births did not diminish the need of recruiting immigrants for economic and social reasons. As a result, France pandered to Algerian migration continuing until the start of the Algerian War of Independence. Although France chose European immigrants rather than non-European immigrants, French society was burdened with the sense of colonial obligation to the Algerian population. And what is more, the Algerians were French nationals and could move freely from Algeria to France. Thanks to very effective government immigration-promoting efforts, there was an inrush of immigrants over the 1945 to 1974 period, which contributed to a rapid population growth (especially of non-European immigrants). As a result of this period the immigrant population continued to grow.

\section{Methods}

Since then, there have been significant changes. French statistics show that in France alone 150,000 foreigners acquire French citizenship every year (https://www.immigration.interieur.gouv.fr). According to the UN, the number of migrants in Germany and Great Britain is more than in France - 9.8 million, 7.8 million people. and 7.4 million (according to Eurostat - more than 7.6 million), respectively. As a percentage of the population, according to Eurostat, these figures are $7.4 \%$ in Germany, $8.1 \%$ in the UK and $8.3 \%$ in France. Of the 7.6 million migrants, 5.5 million were born in third countries and only 2.1 million were from other EU member states. Of the 5.5 million migrants from third countries, 4 million are from the Maghreb countries (http://unhcr.ru/index.php?id=10\&tx_ttnews).

Like all other developed countries, the problem of the growth of an aging population is urgent in France today. According to INSEE forecasts, in France, if the current trend continues, then in 2060 one in three people will be over the age of 60 (Département des statistiques, des étudeset de la documentation). This problem is especially dangerous in terms of financing the pension system. But since the emigrant population is relatively young, immigration can thus temporarily solve this problem by having increased the share of the working population.

However, the solution to the problem mentioned above may lead to another equally critical problem. The prediction of K. Shozhnikki and L. Ragu is that at the current rate of migration (based on data for 2010), by 2050 the population of France will have doubled, and the share of immigrants will be $41 \%$ of the total population. In addition, immigrants will also support statistics on population aging, and therefore, in the long term, the problem of population aging will have never be solved (Chojnicki \& Ragot, 2012).

\section{Results and Discussion}

If earlier no one paid attention to the migration stream, now the flow of migrants is perceived as a threat to national identity, both in France and in Germany. The question then becomes, how can 
the influx of migrants from the East or from Africa affect European identity, if, according to Paul Ricoeur, European universality implies pluralism of cultures? (Ricoeur, 2002) Those who see a threat to themselves in the other's dissimilarity are unsure of themselves. Maybe a threat of migrants is not really the point, but the inability of the modern Western European political elite to positive social construction and the unwillingness of a significant part of the population to step out of their comfort zone?

It is commonly believed that the prerequisites for the current crisis are concealed in an ineffective migration policy and the latest round of technological development, in which "cheap labor" becomes unnecessary and none of the innovations in the economy solve the problem of inequality. Migrants can integrate into European civilization only through participation in the labor process and deconcentration of entrants among the local population. It is just not the case. Modern migrants and their descendants become inhabited in certain areas in French cities, where they live by their own code. Social background and low qualifications hedge all possible means social mobility and breed frustration in this social group. This is evidenced by statistics: the unemployment rate among immigrants from non-European countries was 31.4\% in March 1998 against $11 \%$ for French citizens and already increased to $43 \%$ among people from 15 to 24 years old in 1996 (Demintseva, 2008).

However, the problem under consideration is multifaceted and is unlikely to be completely exhausted by social and economic prerequisites. And other facets we would like to stress very heavily. For example, socio-biological attributes. Today, there is enough evidence of a direct correlation between the structural features of the human brain and the characteristics of an individual's social behavior, such as adaptive potential, a tendency to aggression or violence, altruism or conventionality. It has been established that such aspects of an individual's behavioral nature are determined by the size of limitrophe adaptations between dedicated areas of brain: if they are large enough, then a person is prone to archaic forms of behavior, aggressive ways of solving social problems and intolerant of the existence of competition (Saveliev, 2014). Another thing is also true: the magnitude of the limitrophe adaptations determines the degree of archaism of the brain and, as a consequence, the specificity of behavior. Following the paradigm of tolerance established in the Euro-Atlantic intellectual tradition, the empirically verified fact indicated above is rarely taken into account when discussing the origins of social, in particular, migration problems. For a long time, the questions of a competitive clash of representatives of various ethnoreligious groups were considered through the prism of S. Huntington's concept of a clash of civilizations. Meanwhile, few people reflected on the fact that S. Huntington, following A. Toynbee, subsequently declined his model previously seemed to be balanced. Further research has indicated that the migration crisis in Europe is essentially a model of historical eras that coexist in time, but not "civilizations" (Nazaretyan, 2018). This is where the root of conflict and the tragedy of mutual rejection of the Europeans and immigrants who come from African and Near-Eastern Countries is concealed.

Reorientation of the current situation to a conventional and safe channel is possible only if there is sufficient control from the state and law enforcement agencies. The socialization and acculturation of an individual in the process of the formation of his/her personality has a biologically determined and irreversible character. In other words, it is hardly possible for a person with his/her preconceived beliefs to be re-educated or harmoniously and painlessly integrated into a new cultural environment. In the overwhelming majority of cases, he/she will imitate the norms generally accepted in this society, but not share them. This is confirmed by the unsuccessful efforts of specialized centers in France to de-radicalize extremists.

Let us compare France and Russia. Why are there no Muslim ghettos, national-religious parties and acute interethnic and interreligious tensions in Russian cities? Apparently because from the very beginning there is only labor migration, on the one hand, and strict state control to prevent the massive isolation of immigrants, on the other hand. What do we have in modern France? Muslim ghettos create strong social tension in the cities of France and in the cities throughout Western Europe. People who are not accepted by society and who, from their part, are also not ready to 
accept it, seek support from people like them and, accordingly, adopt a confrontational stand on what the official authorities impose on them. While government agencies are inconsistent and forced to engage in political maneuvering rather than solving the problem. For this reason, integration into society through a community of historical memory, as was customary in European nation states, starting from the 17th century, becomes impossible.

1. The youth movements of the 1980s against racism and xenophobia failed to solve the problems of immigrant youth. Disappointed hopes turned into the growth of influence of radical Islam. According to Gilles Kepel, the role of a mouthpiece for the indigent Maghreb youth after 1989 was assumed by Islamist organizations (Kepel Gilles Jihad,2004). The Union of Muslim Youth (L'Union des jeunes musulmans - UJM) (http://www.ujm.fr/fr/) began to claim the role of a political entity, the Islamic Institute for Humanitarian Studies (L'institut Européen des Sciences Humaines) was founded (https://ieshdeparis.fr). The very fact of their appearance reflects tendencies that French society has not encountered for a long time. The political culture of secularism does not allow Islam to blend with French political culture. Conflict of value systems of this type used to lead, as a rule, to religious wars. The term "Muslim" in French society since the war in Algeria has served to contrast the Arab population of Algeria and the French Algerians. Until 1989, they tried to ignore the problem of Islamization, but after the "political and media hysteria" caused by the hijab case, the authorities were forced to pay attention to it (Amiraux, 2003).

The Muslim question regained its acuteness after September 11, 2001. After this terrorist attack, suspicion of Islamic communities rose steeply, Islamophobia and discrimination on religious grounds intensified (Poli \& Fabbiano, 2013). The main topics discussed were the position of Muslim women in French society and the position of the Muslim population in the urban space, the emergence of contradictions between Islam and state identity.

It should be noted that the "Muslim man/ Muslim woman" category is not clearly defined in France, since after the ban in 1905 to record a religion, no one worried keeping statistics on this topic. There is neither a clear definition of the concept "Muslim", nor exact figures that give a definite idea on this issue. The data of various surveys give too much data precision: from 4 to 6 million people (Dargent, 2010) out of 66 million people in France

\section{Summary}

The image of "border citizens" threatening the national identity of the French was formed on the basis of stereotypes about "Maghrebians" living in France. Does it square with reality? Selfidentification of beurs, as young people of Maghreb descent are now called in France, occurs spontaneously and, as usually happens in such cases, on a negative basis. The inability to get rid of self-image as "other" from the point of view of the indigenous population leads to the fact that young people who grew up in France, most often describe themselves as Europeans or "people of the world", which is facilitated by the process of globalization, the media and the Internet. They most often associate their belonging not with the country of which they are citizens, but with the quarter in which they live. At the same time, their lifestyle is not westernized, they do not want to work at factories like their parents, they are narrow-minded and it is this part of the youth who became those "rebels" who burned cars in 2005 (Demitseva, 2008) This is the part of the population of the outskirts that does not fit in the French world and identifies itself only with the quarter where they live.

However, there are also two other groups: "opportunists" and "cosmopolitans". The first strive not to be isolated in their inner world and increasingly declare that their world has the same right to exist. Assimilation for them is equal to disappearance. Religion for them is a matter of choice, they themselves choose whether to follow traditions or not. The latter put their individuality first, belonging to culture for them is a matter of their personal choice. For them, France is, first of all, a "convenient country" (Demitseva,2008). These people have already severed themselves from the Maghreb community and have no desire to participate in any protest actions. 
The realization that European societies have already and irrevocably become a world of interdependent mixed communities is gradually seizing a strong hold over the minds, but rests on the legacy of colonialism. All the talk of tolerance rests on latent nationalism and a sense of Europe's superiority over the rest of the world. According to Edward Said, "the majority of modern educational systems are infected with nationalism, in other words, they present the meaning of national identity in an idealized form, claiming that it is not subject to any criticism, that it is an embodied virtue" (Said, 2002).

\section{Conclusions}

The matter is complicated by the fact that the concept of national identity has changed, and many people in Europe feel themselves to be Europeans. Europeans will be able to find a solution to the problem associated with the spread of Islamism only if they can combine getting rid of "a longstanding sense of superiority" (Chevènement, 2015) with limiting migration influx and reasonable tightening the legislation in order to prevent the erosion of the common cultural and legal space and blocking growth of socially dependent sentiments in an immigrant environment. For fear of being on the sidelines of the world system, in which the leading role will be assigned to Asia, Europe needs to regain its former confidence in its nations and return to real democracy. This is partly due to the rejection of confrontation with Russia and the focus on mutual exchange of experience. The dialogue of cultures should follow several simple principles: refusal to interfere, respect for the other. The rapprochement fostered by globalization should not be associated with arrogance (Chevènement, 2015).

\section{Acknowledgements}

The work is performed according to the Russian Government Program of Competitive Growth of Kazan Federal University.

\section{References}

[Demitseva E. Being an Arab in France. M.: New Literary Review, 2008. P. 168.

Amiraux V. Discoursvoilélesmusulmanesen Europe. Comment les musulmenssont-ilsdevenues des musulmances // Social Compaces. 2003. Vol. 50. №1. P. 85 - 96.

Chevènement J.-P. Европа выходит из истории? / Jean-Pierre Chevènement: [Russian translation from French by M. Maisuls]. - M.: AST Press, 2015. P. 341.

Chevènement J.-P. Европа выходит из истории? / Jean-Pierre Chevènement: [Russian translation from French by M. Maisuls]. - M.: AST Press, 2015. P. 340.

Chojnicki X., Ragot L. L'immigrationcoûtecher à la France: Qu'enpensent les économistes ?Eyrolles, 2012. 128 p.

Dargent C. La population musulmane de France: de l'ombre à la lumière ? // Revue française de cociologie/ 2010. Vol. 51. №2. P. 219 - 246.

Demintseva E. Being an Arab in France. M.: New Literary Review, 2008. P. 53.

Demitseva E. Being an Arab in France. M.: New Literary Review, 2008. P. 17.

Demitseva E. Being an Arab in France. M.: New Literary Review, 2008. P. 161.

Département des statistiques, des étudeset de la documentation, service statistique ministériel [Electronic resource]. Available at: https://lannuaire.servicepublic.fr/gouvernement/administration-centrale-ou-ministere_165975 free. Access on 03. 13. 2018.

Forced population displacement broke the record and affected one of 113 people [Electronic $\begin{array}{llll}\text { resource] } / \text { УВБK } & \text { OOH. Available at }\end{array}$ http://unhcr.ru/index.php?id=10\&tx_ttnews[tt_news] $=584 \& \mathrm{cHash}=2866954 \mathrm{~b} 240 \mathrm{cec} 0 \mathrm{c} 2 \mathrm{dc}$ db5752a97130e free. Accessed on 03. 13.2018.

http://www.ujm.fr/fr/

https://ieshdeparis.fr/ 
Kepel Gilles Jihad: Expansion and the Decline of Islamism / Russian translation from French by V. F. Denisov. M: Ladomir, 2004. 468p.

Les principalesdonnées de l'immigrationen France [Electronic recource] / Gouv.fr/Info-ressources. Available at https://www.immigration.interieur.gouv.fr/Info-ressources/Etudes-etstatistiques/Statistiques/Essentiel-de-l-immigration/Chiffres-clefs free. Accessed on 03. 13.2018.

Nazaretyan A. P. Global Geopolitics and Russian Influence. [Electronic Resource] / Cybernetics. Available at: https://cyberleninka.ru/article/n/agentura-vliyaniya-v-kontekste-globalnoygeopoliticheskoy-perspektivy free. Accessed on 03.15.2018.

Poli A., Fabbiano D. The Debate on the "Mussulman/Mussulwoman" Category in the French Public Space / Racism, Xenophobia, Discrimination. What sort of them we saw ... / Collected Papers: compiled and edited by Yekaterina Demintseva. - M.: New Literary Review, 2013. P. 278.

Ricoeur P. Universalism and the Power of Difference // Kearnay R. The Dialogues in Europe. M: The "Ves' Mir" Publishing House, 2002. P. 44.

Said E. Europe and Its Foreigners: Arabian Perspective // Kearnay R. The Dialogues about Europe P. M: The "Ves' Mir" Publishing House, 2002. P. 58.

Saveliev S. V. Misery of Brain. M.: VEDI, 2014. P. 123. 